\title{
Final Report of the First Refractory Germ Cell Tumor Treated with Sunitinib Malate
}

\author{
Joan Manel Gasent Blesa ${ }^{a} \quad$ Enrique Grande Pulido ${ }^{a}$ \\ Juan Laforga Canales ${ }^{\mathrm{a}}$ Vicente Alberola Candel ${ }^{\mathrm{b}}$

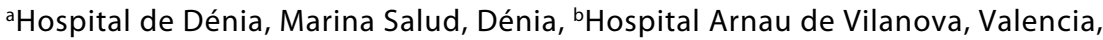 \\ Spain
}

\section{Key Words}

Sunitinib · Chemoresistant · Germ cell cancer · Activity

\begin{abstract}
Patients with advanced germ cell tumors can be cured with cisplatin-based chemotherapy, but the outcome remains unsatisfactory for patients with relapsed disease, including those patients with refractory disease after bone marrow transplantation. Targeted therapies have changed the standard of care for many advanced solid tumors. We have identified, in the literature, potential targets for the treatment of refractory germ cell tumors, and applied to a patient with a refractory disease. We chose sunitinib for this purpose. To our knowledge, this is the first case to be treated with sunitinib, and we have found a promising activity.
\end{abstract}

\section{Introduction}

Cancer of the testis comprises a morphologically and clinically diverse group of neoplasms, most of which are germ cell tumors (GCT). Approximately $90 \%$ of the GCT originate in the testis and $10 \%$ are extragonadal.

20 to $30 \%$ of patients with advanced GCT relapse or fail to achieve a complete response to conventional cisplatin-based chemotherapy. Effective second- and third-line salvage options offer a possibility of cure for those patients whose disease displays a resistance to bleomycin, etoposide and cisplatin (BEP) as first-line therapy.

The chemosensitivity of GCT, a striking dose-response phenomenon for individual drugs, the rare occurrence of bone marrow metastasis, and a young patient population permit administration of high-dose chemotherapy (HDT) with refractory GCT. Options for patients who recur after bone marrow transplantation are few and patients usually have a bad prognosis. 
Sunitinib (SU011248; SUTENT ${ }^{\circledR}$, Pfizer Inc., New York, N.Y., USA) is a rationally designed small molecule that inhibits members of the split-kinase domain family of receptor tyrosine kinases (RTKs), including the vascular endothelial growth factor receptors (VEGFRs) types 1 and 2 (FLT1 and FLK1/KDR), platelet-derived growth factor receptors (PDGFR- $\alpha$ and PDGFR- $\beta$ ), stem cell factor receptor c-KIT, and FLT3 and RET kinases [1-3]. Inhibition of these RTKs blocks signal transduction, thereby affecting many of the processes involved in tumor growth, progression, metastasis, and angiogenesis [4]. The VEGF, basic fibroblast growth factor (bFGF), and PDGF-signaling pathways are critical in the transduction of extracellular signals and the induction of angiogenesis [1]. Angiogenesis plays a vital role in the growth and metastasis of solid and hematologic malignancies [5]. Receptors such as c-KIT, FLT3, and RET are also important in signal transduction and growth in solid tumors, including gastrointestinal stromal tumors (GIST), small-cell lung cancer, thyroid carcinoma, and hematologic malignancies such as lymphomas and leukemias $[1,6,7]$.

\section{RTK Inhibition by Sunitinib}

RTKs are transmembrane proteins at the cell surface that transduce extracellular signals to the cytoplasm $[1,2]$. These proteins contain extracellular ligand-binding domains and intracellular catalytic domains. Ligand binding induces dimerization of these RTKs resulting in autophosphorylation of the cytoplasmic domains and activation of tyrosine kinase activity. Tyrosine kinase activation further stimulates multiple downstream signaling pathways that modulate DNA synthesis, cell division, growth, progression, migration, differentiation, and cell death $[1,2]$. The predominant RTKs that have been demonstrated to be inhibited by sunitinib are VEGF, PDGF, bFGF, KIT, FLT3, CSF-1, and RET $[3,8]$

\section{VEGF, PDGF, and bFGF RTK Inhibition}

VEGF is a robust growth factor for endothelial cell proliferation and angiogenesis that promotes the vascularization required for primary tumor growth and for establishing new metastatic foci $[5,9]$. An abundance of data exists that associates excessive levels of VEGF expression with increased microvascular density, cancer recurrence, and decreased survival. The VEGF receptors, VEGFR1 (also known as Flt-1), VEGFR2 (also known as Flk1 or KDR), and VEGFR3 (also known as Flt4), possess tyrosine kinase activity that promotes intracellular signaling, leading to downstream effects on angiogenesis [10]. PDGF has two receptor types, $\alpha$ and $\beta$, which are both overexpressed in many solid tumors as well as in the surrounding stroma $[1,11]$. PDGFR is upregulated during tumor progression to stimulate the growth and proliferation of pericytes and fibroblasts that surround and support endothelial cells [12]. bFGF and its receptor are expressed in a variety of tumors and are involved in promoting tumor growth directly, or indirectly, through stimulation of angiogenesis and induction of VEGF expression [10].

Doses of 20 to $40 \mathrm{mg} / \mathrm{kg} /$ day were needed to achieve the target plasma concentrations (50 to $100 \mathrm{ng} / \mathrm{ml}$ ) required to demonstrate inhibition of VEGFR2 and PDGFR phosphorylation [3]. 


\begin{tabular}{|c|c|c|c|}
\hline $\begin{array}{r}\text { Cose Reports in } \\
\text { Bincialy }\end{array}$ & $\begin{array}{l}\text { Case Rep Oncol 2009;2:234-241 } \\
\text { D0I: 10.1159/000260901 }\end{array}$ & Published online: December 11, 2009 & $\begin{array}{l}\text { @ } 2009 \text { S. Karger AG, Basel } \\
\text { ISSN 1662-6575 } \\
\text { www.karger.com/cro }\end{array}$ \\
\hline
\end{tabular}

\section{Other RTKs Inhibited by Sunitinib}

FLT3 RTK Inhibition. FLT3 (fms-related tyrosine kinase, Flk2, stk-2) is expressed on immature hematopoietic progenitors as well as some mature myeloid and lymphoid cells $[7,13]$. This RTK regulates the survival and proliferation of hematopoietic progenitor cells, whereas mutations of FLT3 in acute myelogenous leukemia (AML) are associated with enhanced proliferation and survival of leukemic blasts [7].

KIT, CSF-1R, and RET RTK Inhibition. c-KIT is produced by the KIT gene, which is expressed on hematopoietic progenitor cells, mast cells, germ cells, and the interstitial cell of Cajal $[6,14]$. Steel factor (SLF or stem cell factor) is the ligand that binds to c-KIT and initiates signal transduction. c-KIT has been implicated in mastocytosis/mast cell leukemia, germ cell cancers, small-cell lung cancer, GISTs, AML, neuroblastoma, melanoma, and ovarian and breast carcinoma $[6,15]$. Despite these in vitro cellular potencies, sunitinib doses of 40 to $80 \mathrm{mg} / \mathrm{kg} /$ day were still required to produce adequate plasma levels for inhibition of the c-KIT RTK.

Colony-stimulating factor (CSF)-1R is a c-fms gene product that exists on monocytic progenitors $[16,17]$. The osteoclastogenic factor, macrophage CSF produced by tumor cells, binds to the CSF-1R receptors to stimulate osteoclasts and enhance the osteolytic activity of osteoclasts. A mutant form of the RET proto-oncogene RTK is involved in the multiple endocrine neoplasia types $2 \mathrm{~A}$ and $2 \mathrm{~B}$ autosomal dominant syndromes, familial medullary thyroid carcinoma, and perhaps sporadic neuroendocrine tumors [2, 18]. In cultured TT human medullary thyroid carcinoma cells with an active RET mutation, sunitinib inhibited RET autophosphorylation with an $\mathrm{IC}_{50}$ of approximately $100 \mathrm{nmol} / \mathrm{l}$, indicating that these tumors may be an appropriate target for disease-directed studies [19].

\section{Rationale for the Use of Sunitinib in GCT}

RTKs play a major role during all developmental stages of the male gonad. The RTK c-KIT is a key regulator of spermatogenesis that was detected in early gonadal development [20]. Its ligand, stem cell factor (SCF), is produced by the Sertoli cells of the testis [21]. c-KIT is expressed in $80-100 \%$ of seminomas but in only $7-32 \%$ of nonseminoma tumors [22]. Activating c-KIT mutations are rare in GCTs [23]. c-KIT mutations in exon 17 were detected in 3/224 unilateral and 57/61 bilateral GCTs [24]. Physiological and neoplastic angiogenesis are mediated by vascular endothelial growth factor (VEGF) and its action on the receptor vascular endothelial growth factor receptors (VEGFR) and other growth factors. VEGF binds to the RTKs VEGFR1 and VEGFR2, which are expressed on endothelial cells. While VEGFR1 and VEGFR2 are almost undetectable in normal testis, both receptors are overexpressed in tumor endothelial cells and in GCTs themselves [25, 26]. VEGF mRNA and protein is also significantly overexpressed in GCTs. VEGF expression correlates with the microvascular density within the tumors and allows for the identification of patients at risk for metastatic disease in some [27] though not all studies [28].

Platelet-derived growth factor (PDGFR) has been implicated in the development of the male gonad [29], and platelet-derived growth factor (PDGF) and PDGFR are important for the development of Leydig cells and myoid cells. Also, PDGFR has been detected in testicular GCT [30] during the initial stages of GCT development [31]. 


\begin{tabular}{|c|c|c|c|}
\hline $\begin{array}{r}\text { Cose Reports in } \\
\text { ince.til }\end{array}$ & $\begin{array}{l}\text { Case Rep Oncol 2009;2:234-241 } \\
\text { D0I: } 10.1159 / 000260901\end{array}$ & Published online: December 11, 2009 & $\begin{array}{l}\text { (c) } 2009 \text { S. Karger AG, Basel } \\
\text { ISSN } 1662-6575 \\
\text { www.karger.com/cro }\end{array}$ \\
\hline
\end{tabular}

Here we present what is, to our knowledge, the first case reported in the literature of a patient with a metastatic GCT, refractory to HDT, who progressed after bevacizumabbased chemotherapy, and in whom sunitinib showed clinical activity.

\section{Clinical Case}

A 24-year-old male patient was sent to our unit from another center. He was diagnosed in 2005 of an enlarging left testicular mass. In July 2005, he was operated with a left inguinal orchiectomy. The pathologic study revealed a mixed GCT with areas of seminoma, choriocarcimona and endodermal sinus tumor. Human chorionic gonadotropin (HCG) was $329 \mathrm{IU} / \mathrm{ml}(<5 \mathrm{mIU} / \mathrm{ml})$, and alphafetoprotein (AFP) of $8,730 \mathrm{ng} / \mathrm{ml}$ (>10 ng/ml); lactate dehydrogenase (LDH) was normal. The extension study revealed multiple lung nodules compatible with metastatic extension, 2 liver metastases of 77 and 60 $\mathrm{mm}$ and 2 retroperitoneal masses of $15 \mathrm{~cm}$ each.

The patient received 4 cycles of BEP (bleomycin $30 \mathrm{mg}$ i.v. day 1,8 , 15; etoposide $120 \mathrm{mg} / \mathrm{m}^{2}$ day 15 ; and cisplatin $20 \mathrm{mg} / \mathrm{m}^{2}$ day $1-5$ ) every 3 weeks, obtaining only a partial response. All the lung nodules disappeared, liver metastases did not show any change, and the retroperitoneal masses presented partial response. Subsequently, the patient was offered to continue chemotherapy with paclitaxel $250 \mathrm{mg} / \mathrm{m}^{2}$ followed by ifosfamide $1,500 \mathrm{mg} / \mathrm{m}^{2}$ days $2-5$, and cisplatin $25 \mathrm{mg} / \mathrm{m}^{2}$ days $2-5$, mesna $500 \mathrm{mg} / \mathrm{m}^{2} 4 \mathrm{~h}$ before and $8 \mathrm{~h}$ after each dose of ifosfamide (TIP). He completed 4 cycles, obtaining a complete clinical remission. HCG was $23 \mathrm{mIU} / \mathrm{ml}$ and AFP $20 \mathrm{ng} / \mathrm{ml}$. At this time, a PET/CT was performed and did not reveal any hypercaptation area; thus, the patient was considered for follow-up.

In January 2007, biochemical (HCG 2,142 $\mathrm{mIU} / \mathrm{ml}$ ) and radiological progression in the liver and retroperitoneal lymph nodes were documented. The patient initiated TIP chemotherapy for a total of 3 cycles, with a complete clinical response, followed by an autologous bone marrow transplant (BMT). The conditionating treatment consisted of etoposide $750 \mathrm{mg} / \mathrm{m}^{2}$ and carboplatin $700 \mathrm{mg} / \mathrm{m}^{2}$ days -6 to -4 ; and on April 27 $7^{\text {th }}, 2007$, stem cells were infused at $4.43 \times 106$ CD $34+/ \mathrm{kg}$. A complete clinical and serological response was obtained and the patient was included in a follow-up program.

In December 2007, an increase of HCG levels to $1,881 \mathrm{mIU} / \mathrm{ml}$ with a negative CT and PET was detected. The patient began chemotherapy with oxaliplatin $85 \mathrm{mg} / \mathrm{m}^{2}$ day 1 . After 3 cycles of chemotherapy, HCG level increased to $21,332 \mathrm{mIU} / \mathrm{ml}$, and liver, lung and retroperitoneal metastases were observed. The patient then came to our center.

After evaluating the case, we decided to consider chemotherapy with carboplatin AUC 5-docetaxel $60 \mathrm{mg} / \mathrm{m}^{2}$ and bevacizumab $10 \mathrm{mg} / \mathrm{kg}$ every 3 weeks, under compassionate use, based on the results obtained by the group of Voigt et al. [32]. After 3 cycles of chemotherapy, the CT scan revealed liver, lung and retroperitoneal progression, HCG was then $27,865 \mathrm{mIU} / \mathrm{ml}$, thus the treatment was discontinued; a new compassionate use authorization for treatment with sunitinib was solicited and authorized.

The patient began sunitinib $37,5 \mathrm{mg}$ on a daily basis in June 2008. The initial level of HCG was $37,258 \mathrm{mIU} / \mathrm{ml}$. After 2 weeks of treatment, it had increased to $73,782 \mathrm{mIU} / \mathrm{ml}$, and after 4 weeks, it had decreased to $36,153 \mathrm{mIU} / \mathrm{ml}$; in week 6 it was $25,155 \mathrm{mIU} / \mathrm{ml}$, which could be considered similar to the flare effect that sometimes happens with sunitinib in prostate cancer (fig. 1). The control at day 60 reflected 22,365 $\mathrm{mIU} / \mathrm{ml}$ and on the last disposable control on day 75, the level of HCG was at 19,805 $\mathrm{mIU} / \mathrm{ml}$. A new CT scan was performed which showed, compared with the scan performed in May, an increase in size of the retroperitoneal lesions, but with an increase of necrosis, close to the response observed with gastrointestinal stromal tumors (igg. 2 ). After day 75, the patient came to the emergency room of our hospital and died with a massive retroperitoneal bleeding and hematuria after a motocross accident.

\section{Discussion}

The treatment of patients with GCT has evolved significantly over the past 30 years because cisplatin-based chemotherapy plus adjunctive surgery cures advanced metastatic tumors and the potential rescue of patients with BMT exists. For patients who progress after BMT, the only accepted treatment in this context is the combination of gemcitabine 
and oxaliplatin [33], which may offer prolonged survival for some patients. Treatment of refractory patients is challenging and in many of them it harbors an evolution that marks the onset of inexorable terminal progression. The only exception to this rule are patients with elevated serum markers and a solitary site of metastases. Effective treatments are urgently needed for salvage treatment of patients whose disease progresses and becomes chemoresistant. A rationale exists for the use of sunitinib in these patients based on the genetic aberrations of tumors that involve VEGT, c-KIT and PDGFR, which are all inhibited by the drug.

To our knowledge, this is the first reported case of a GCT treated with sunitinib. Because of the obtained result we can recommend its use and development in the treatment of refractory GCT.

Fig. 1. Evolution of the HCG level.

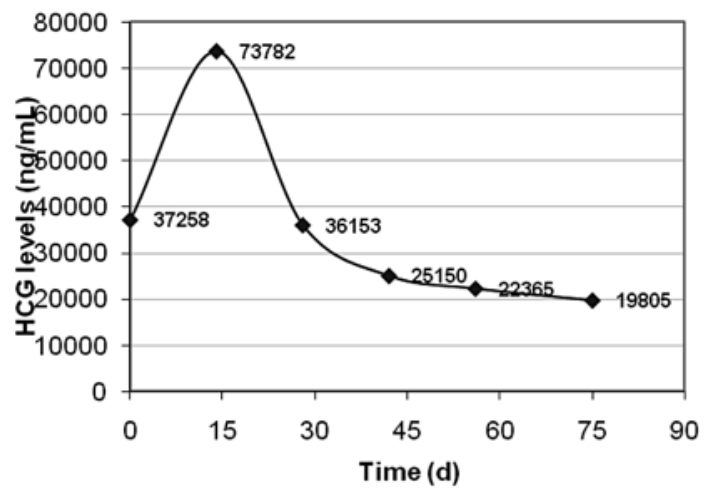




\begin{tabular}{c|l|l|l}
$\begin{array}{c}\text { Cose Reports in } \\
\text { Oncolayly }\end{array}$ & $\begin{array}{l}\text { Case Rep Oncol 2009;2:234-241 } \\
\text { D0I: 10.1159/000260901 }\end{array}$ & Published online: December 11, 2009 & $\begin{array}{l}\text { O 2009 S. Karger AG, Basel } \\
\text { ISSN 1662-6575 } \\
\text { www.karger.com/cro }\end{array}$ \\
\hline
\end{tabular}

Fig. 2. Upper panel: CT scan May 2008. Lower panel: CT scan July 2008.
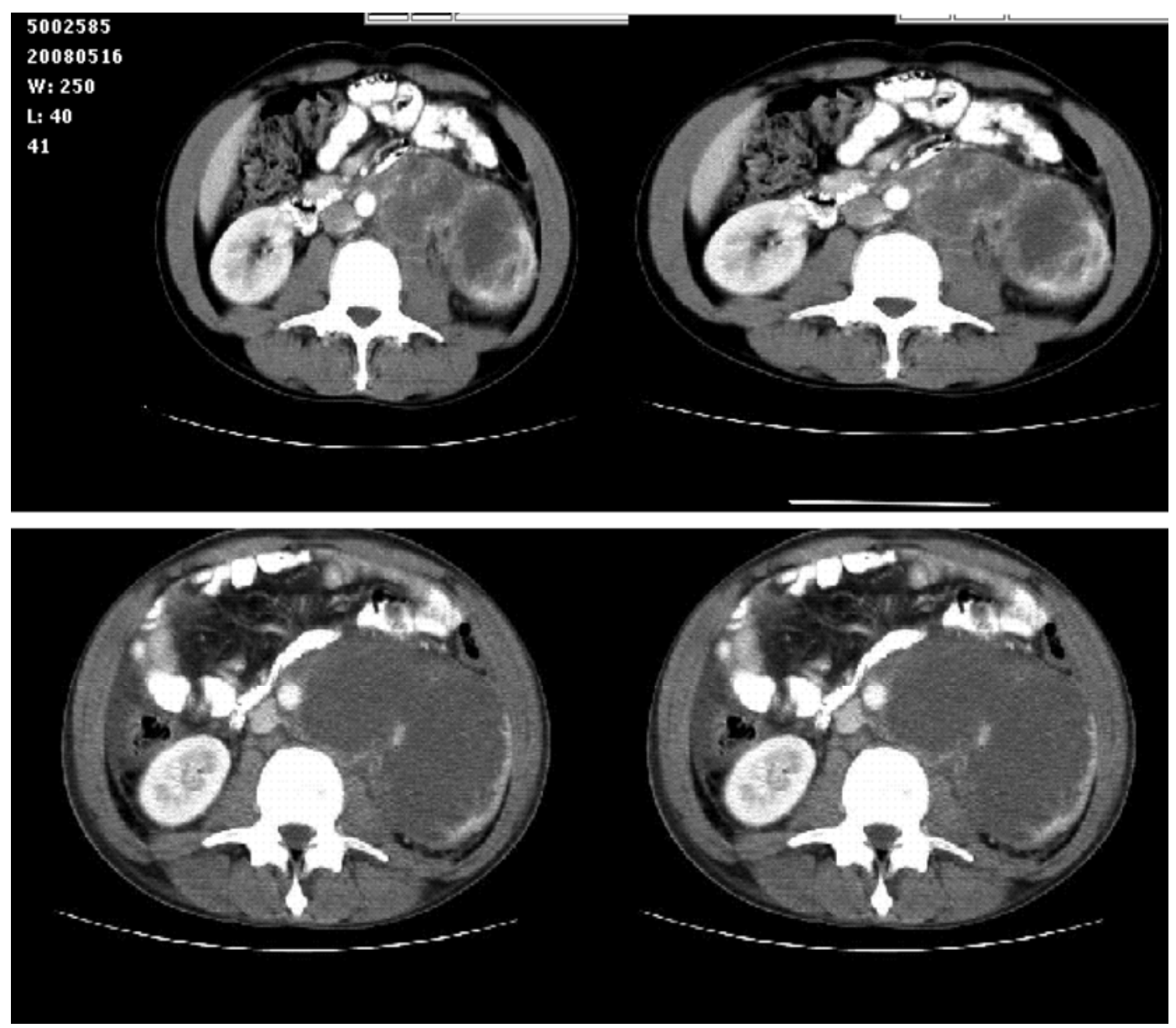


\begin{tabular}{|c|c|c|c|}
\hline $\begin{array}{l}\text { Case Reports in } \\
\text { inceny }\end{array}$ & $\begin{array}{l}\text { Case Rep Oncol 2009;2:234-241 } \\
\text { D0I: 10.1159/000260901 }\end{array}$ & Published online: December 11, 2009 & $\begin{array}{l}\text { (c) } 2009 \text { S. Karger AG, Basel } \\
\text { ISSN } 1662-6575 \\
\text { www.karger.com/cro }\end{array}$ \\
\hline
\end{tabular}

\section{References}

1 Arora A, Scholar EM: Role of tyrosine kinase inhibitors in cancer therapy. J Pharmacol Exp Ther 2005;315:971-979.

12 Pawson T: Regulation and targets of receptor tyrosine kinases. Eur J Cancer 2002;38:S3-S10

3 Mendel DB, Laird AD, Xin X, et al: In vivo antitumor activity of SU11248, a novel tyrosine kinase inhibitor targeting vascular endothelial growth factor and plateletderived growth factor receptors: determination of a pharmacokinetic/ pharmacodynamic relationship. Clin Cancer Res 2003;9:327-337.

4 Hanahan D, Weinberg RA: The hallmarks of cancer. Cell 2000;100:57-70.

5 Ferrara N, Gerber HP, LeCouter J: The biology of VEGF and its receptors. Nat Med 2003;9:669-676.

6 Heinrich MC, Blanke CD, Druker BJ, et al: Inhibition of KIT tyrosine kinase activity: a novel molecular approach to the treatment of KIT-positive malignancies. J Clin Oncol 2002;20:1692-1703.

7 Schmidt-Arras D, Schwable J, Bohmer FD, et al: Flt3 receptor tyrosine kinase as a drug target in leukemia. Curr Pharm Des 2004;10:1867-1883.

8 Mendel DB, Laird AD, Li G, et al: Development of a preclinical pharmacokinetic/pharmacodynamic relationship for the angiogenesis inhibitor SU11248, a selective inhibitor of VEGF and PDGF receptor tyrosine kinases in clinical development. Proc Am Soc Clin Oncol 2002;20:24 (abstract 94).

19 Parikh AA, Ellis LM: The vascular endothelial growth factor family and its receptors. Hematol Oncol Clin North Am 2004;18:951-971.

10 Osusky KL, Hallahan DE, Fu A, et al: The receptor tyrosine kinase inhibitor SU11248 impedes endothelial cell migration, tubule formation, and blood vessel formation in vivo, but has little effect on existing tumor vessels. Angiogenesis 2004;7:225-233.

$\checkmark 11$ Sedlacek HH: Kinase inhibitors in cancer therapy: a look ahead. Drugs 2000;59:435-476.

12 Sundberg C, Ljungstrom M, Lindmark G, et al: Microvascular pericytes express platelet-derived growth factor-beta receptors in human healing wounds and colorectal adenocarcinoma. Am J Pathol 1993;143:1377-1388.

13 O'Farrell AM, Abrams TJ, Yuen HA, et al: SU11248 is a novel FLT3 tyrosine kinase inhibitor with potent activity in vitro and in vivo. Blood 2003;101:35973605.

14 Krystal GW, Honsawek S, Kiewlich D, et al: Indolinone tyrosine kinase inhibitors block Kit activation and growth of small cell lung cancer cells. Cancer Res 2001;61:3660-3668.

15 Krystal GW, Honsawek S, Kiewlich D, et al: Indolinone tyrosine kinase inhibitors block Kit activation and growth of small cell lung cancer cells. Cancer Res 2001;61:3660-3668.

16 Kacinski BM: CSF-1 and its receptor in ovarian, endometrial and breast cancer. Ann Med 1995;27:79-85.

17 Toy EP, Chambers JT, Kacinski BM, et al: The activated macrophage colonystimulating factor (CSF-1) receptor as a predictor of poor outcome in advanced epithelial ovarian carcinoma. Gynecol Oncol 2001;80:194-200.

18 Skinner MA, Safford SD, Freemerman AJ: RET tyrosine kinase and medullary thyroid cells are unaffected by clinical doses of STI571. Anticancer Res 2003;23:3601-3606.

19 Chow L, Eckhardt SG: Sunitinib: from rational design to clinical efficacy. J Clin Oncol 2007;25:884-896.

20 Manova K, Nocka K, Besmer P, Bachvarova RF: Gonadal expression of c-kit encoded at the W locus of the mouse. Development 1990;110:1057-1069.

-21 Rossi P, Albanesi C, Grimaldi P, Geremia R: Expression of the mRNA for the ligand of c-kit in mouse Sertoli cells. Biochem Biophys Res Commun 1991;176:910-914.

22 Izquierdo MA, Van Der Valk P, Van Ark-Otte J, et al: Differential expression of the c-kit proto-oncogene in germ cell tumours. J Pathol 1995;177:253-258. 
23 Sakuma Y, Sakurai S, Oguni S, et al: Alterations of the c-kit gene in testicular germ cell tumors. Cancer Sci 2003;94:486-491.

24 Looijenga LH, De Leeuw H, Van Oorschot M, et al: Stem cell factor receptor (cKIT) codon 816 mutations predict development of bilateral testicular germ-cell tumors. Cancer Res 2003;63:7674-7678.

25 Olivarez D, Ulbright T, Deriese W, et al: Neovascularization in clinical stage A testicular germ cell tumor: prediction of metastatic disease. Cancer Res 1994;54:2800-2802.

26 Viglietto G, Romano A, Maglione D, et al: Neovascularization in human germ cell tumors correlates with a marked increase in the expression of the vascular endothelial growth factor but not the placenta-derived growth factor. Oncogene 1996;13:577-587.

27 Fukuda S, Shirahama T, Imazono Y, et al: Expression of vascular endothelial growth factor in patients with testicular germ cell tumors as an indicator of metastatic disease. Cancer 1999;85:1323-1330.

28 Adam M, Schmidt D, Wardelmann E, et al: Angiogenetic protooncogene ets-1 induced neovascularization is involved in the metastatic process of testicular germ cell tumors. Eur Urol 2003;44:329-336.

29 Nurmio M, Toppari J, Zaman F, Andersson AM, Paranko J, Söder O, Jahnukainen K: Inhibition of tyrosine kinases PDGFR and C-Kit by imatinib mesylate interferes with postnatal testicular development in the rat. Int J Androl 2007;30:366-376.

-30 Sihto H, Sarlomo-Rikala M, Tynninen O, et al: KIT and platelet-derived growth factor receptor alpha tyrosine kinase gene mutations and KIT amplifications in human solid tumors. J Clin Oncol 2005;23:49-57.

-31 Mosselman S, Looijenga LH, Gillis AJ, van Rooijen MA, Kraft HJ, van Zoelen EJ, Oosterhuis JW: Aberrant platelet-derived growth factor alpha-receptor transcript as a diagnostic marker for early human germ cell tumors of the adult testis. Proc Natl Acad Sci USA 1996;93:2884-2888.

-32 Voigt W, Kegel T, Maher G, Jordan K, Müller L, Schmoll H-J: Bevacizumab plus high-dose ifosfamide, etoposide and carboplatin (HD-ICE) as third-line salvage chemotherapy induced an unexpected dramatic response in highly platinum refractory germ-cell cancer Ann. Onc 2006;17:531-533.

33 Pectasides D, Pectasides M, Farmakis D, et al.: Gemcitabine and oxaliplatin (GEMOX) in patients with cisplatin-refractory germ cell tumors: a phase II study. Ann Oncol 2004;15:493-497. 